\title{
AN IMPACT OF WOVEN KASUTI NEGI MOTIFS IN ILKAL SAREES
}

\section{USING REGENERATED CELLULOSE YARNS}

\author{
JYOTHI KORDHANYAMATH ${ }^{1}$ \& Dr. S. KAUVERYBAI ${ }^{2}$ \\ ${ }^{I}$ Assistant Professor, Acharya Institute of Graduate Studies, Bangalore, India \\ ${ }^{2}$ Associate Professor, Smt V H D Central Institute of Home Science Bangalore, India
}

\begin{abstract}
India has a diverse and rich textile tradition which is known for its beauty and ethnicity. The textiles are highly appreciated all over the world and considered as prestigious possession by everyone. Ilkal is one of the traditional textiles which is famous all over the world. Topeteniseragu and kondi techniques are the unique factors of Ilkal saree. The strength and magnificence of the Ilkal sarees makes it one of the favourites among women. The present study aims at revival of traditional IIkal sarees with two concepts. First one is to weave a kasutinegi motif in Ilkalsaree and second one is to introduce regenerated cellulose yarns in weaving Ilkalsaree. The kasuti motifs are being woven into Ilkal sarees with jacquard setup using extra set of weft yarns.
\end{abstract}

KEYWORDS: Ilkal, Topeteni, Kondi Technique, Negi Motif \& Regenerated Cellulose Yarns

Received: May 14, 2019; Accepted: Jun 04, 2019; Published: Jul 01, 2019; Paper Id.: IJTFTAUG20191

\section{INTRODUCTION}

India is a country with diversified customs and cultures. Ilkal is famous by the name of Ilkal town in Karnataka. It is nearer to the borders of two states Maharashtra and Andhra Pradesh. Ilkal is primarily a weaver's town, located in the north part of Karnataka. Production of Ilkal textile is family business in Ilkal and all the family members are involved in this process irrespective of caste and creed. The Saree is result of traditional methods of hand weaving that have been developed over the centuries and passed down through generations.

The uniqueness of saree is joining of the body warp with pallu warp with a series of loops locally called as TOPE TENI technique. The saree is woven in 6 yards, 8 yards, 9 yards. The pallu portion is known as TOPE TENI SERAGU. The tope teniseragu has 3 solid portions in red colour, and in between 2 portions are white in color. Chikki, Gomi, Jariand Gadidadi are the traditional borders used in Ilkalsarees and the width of boarders ranges from $2.5 "$ to $4 "$.

The specificity of Ilkalsaree not only lies in the construction process but also with surface ornamentation using kasuti embroidery. Kasuti embroidery is a traditional embroidery of North Karnataka. Gavanti, Murgi, Negi. Methi are the four stitches used for kasutiembroidery. Among these four stitches, Negi is the stitch which is lesser used for embroidery. Mahale (1998) observed in her study on 'Folk embroidery of Karnataka' that Negi stitch was rarely used and stated that a large proportion of commercial embroiderers possessed problems of backache and strenuousness to eyes since the embroidery was done by counting threads in the fabric.

Since its inception, Ilkalsarees are commonly manufactured using cotton, silk and art silk. Subsequently, an attempt is made to introduce regenerated cellulose yarns. Regenerated cellulose yarns such as modal, bamboo 
and banana excel in comfort properties. They are bio-degradable, echo-friendly, anti-microbial and stronger in nature. They are even soft and resists creasing. The fiber dyes are handy and yield deep, brilliant colors; neither do they bleed color in the cleaning process. Among the three mentioned fibers, modal and banana fibers are lustrous in nature. Based on the study conducted, cotton, bamboo, modal and banana yarns are selected to develop the products in different combination.

Ilkalsaree industry has a 1000 year old tradition. The rich tradition harbors the provision of developing the kasutiembroidery that may else sink in obscurity. The necessity is not merely to promote either of them but to revive the both that may otherwise go extinct. The present study focuses on the revival of traditional Ilkalsarees and kasutiNegi motif. Cotton*modal and cotton*bamboo are the two combinations used to develop sarees. Kasuti Negi motif on Ilkalsarees through handloom weaving using jacquard set up is the technique adopted in the present study. The designs are woven with warp as cotton, weft with modal or bamboo, banana yarns are used as extra set of weft yarn to get Negi design effects.

\section{Aim}

To design and develop Ilkalsarees with woven kasuti Negi motif using regenerated cellulose yarns.

\section{Objectives}

- To select and implement Modal, Bamboo and Banana yarns in Ilkalsarees.

- To select the traditional Negi motif.

- To transfer hand embroidery motif to weaving.

- To weave traditional kasutiNegi motifs in Ilkalsarees.

- To get the acceptance from the traditional weavers.

\section{Scope}

Variety is refreshing and appealing to the human minds. The Indian textiles are endowed with versatility that privileges experimentation in style and techniques. The creative minds may bring home endless creations that appeals the onlookers and steals their attention. The surging desire for the new and beautiful with the best of the techniques adopted is constantly sought for. In due consideration to the aforesaid, the present study attempts at a refreshingly replenished look for Ilkalsarees not losing sight of its originality and specificity. The study is hopeful of paving way to further experimentation in style, technique and the combination of yarns/colours that goes in the making of Ilkalsaree.

\section{METHODOLOGY}

\section{Collection of Data}

- Primary source of information on Ilkal traditional textiles are collected from traditional weavers of Ilkal.

- Interviews were held with the traditional weavers of Ilkal; To know the details and innovation in the field of Ilkal traditional textiles. The feedback and output is duly considered in the study.

- Information collected from different retail units of Ilkal and Bengaluru to know the availability, production, materials used and products in Ilkal textiles. 
- Related Literature is collected on the application of regenerated cellulose yarns on traditional weaving technique of Ilkal.

\section{Product Development}

- Selection of Raw Material

- Cotton yarn-1 kg.

- Modal/Bamboo-650gms

- Banana yarn-200gms.

The above listed quantity goes in the making of a single saree. The same amount of yarn was used for another saree, but modal is replaced by bamboo yarn. In total, two sarees are developed: one with cotton*modal and another with cotton*bamboo in two different colors. Banana yarns are used to obtain Negi motif effect as extra weft for weaving both the sarees.

- Selection of Dyes: Vat dye is used considering the good color fastness property

- Selection of Color: Crème (scoured yarn), vat dyes: Pink-P. n-18-1635, Green-P. n-17-0133,

- Motif Selection: A floral geometric Negi motif is selected for weaving.

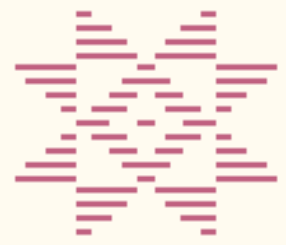

Figure 1: Negi Motif (Floral Pattern)

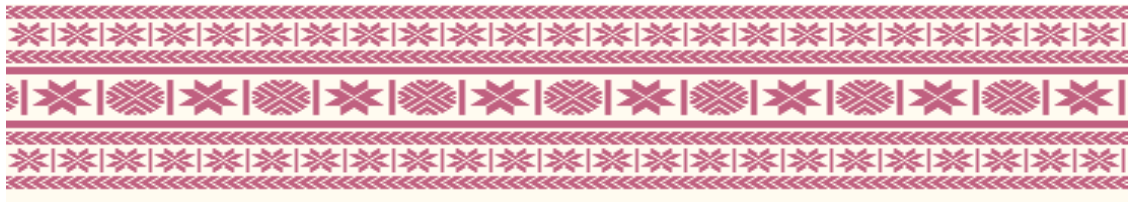

Figure 2: Boarder Design (GadiDadi Pattern)

- Digitizing the Kasuti Negi Motif: The motif to be woven is first conceptualized and drawn on a graph using SOFTWARE JASC PAINT SHOP PRO 9. The motif is made of a particular size to suit the jacquard needle capacity of 120 hooks. The graph acts like a guide to understand the placement of warp and weft yarns to get the desired pattern

- Punch Card Preparation, Lacing: The graph helps in preparing the punch cards to obtain the design. Holes are punched in the jacquard cards using conventional card cutting machine. The punch cards are serially placed and tied with a cord. The first card and last card are joined and secured together by a knot that helps in repeating the design 
- Jacquard set up: Handloom with jacquard 120 needle capacity is set to weave kasutiNegi motifs in Ilkalsarees. 120 hooks jacquard is mounted on a wooden square box on top of the loom. The laced jacquard cards are fixed on top of the loom in connection with needles. The jacquard needles are connected to warp threads wherever the design is required. 104 needles are utilized to form the design. A complex series of threads are arranged in such a manner that lifting of a particular set of threads results in the lifting of a particular set of warp yarns which results in the formation of draft and peg plan required for a single repeat.

- Pirn Winding: Pirn winding is done for modal, bamboo and banana. The hank is mounted on the wheel and the pirn is mounted on the shaft. The yarn from the hank is transferred on to the pirn by rotating the wheel and bobbin.

- Warping and Weaving: The technique of Ilkal requires the preparation of warp separately for each saree. The same warp can't be used in making of multiple number of sarees. Ball warping and Mandola technique is used since beaming is not required for Ilkalsarees. Warp threads for body is prepared separately using cotton yarns that are cream in color. Similarly, pallu warp is prepared separately with cotton threads that are pink in color. Border portion of warp is prepared with similar color threads that are used in pallu warp with cotton threads. The pallu threads and body threads are joined in loops with a kondi technique. First, the pallu of the saree is woven. The topeteniseragu is formed using three shuttles. After the pallu is woven, the series of loops are cut and stretched at the back of the loom for further weaving process. The kasutiNegi motifs are woven on the body of the sarees using a extra set of weft yarn as swivel patterns to give a embellished look. Once the saree is woven for a required length, it is cut and taken away from the loom. The warping is prepared for the next saree in different color combination following the similar process of weaving. The products are developed at Weavers Service Center, Bangalore.

- Acceptance Phase: Assessment of sarees is carried out with interview schedule and a questionnaire. Acceptance is taken from 30 traditional weavers who are specialized in weaving

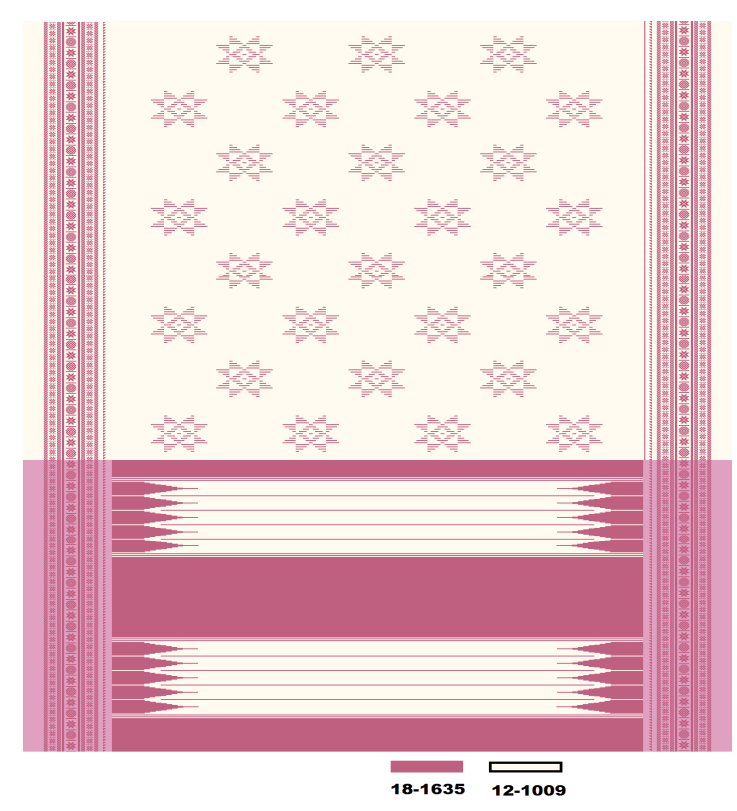

Figure 3: Sample 1-Design of the Saree 


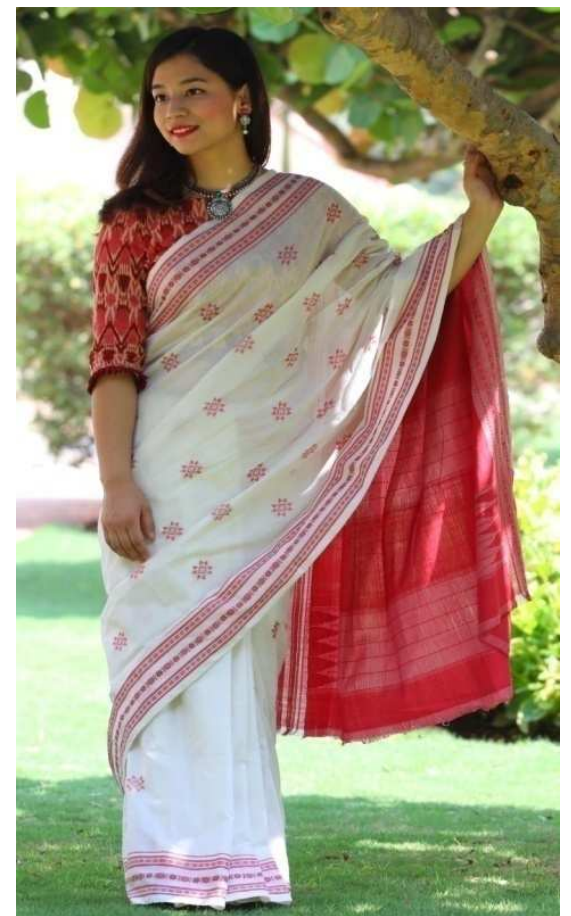

Figure 4: Sample 2- Developed Saree (Cotton*Modal)

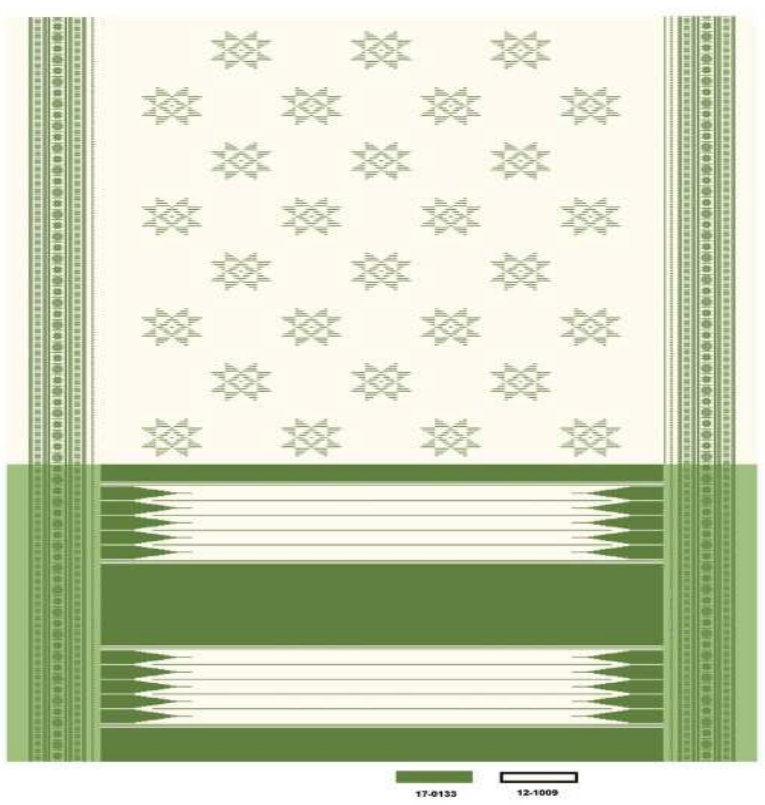

Figure 5: Design of the Saree 


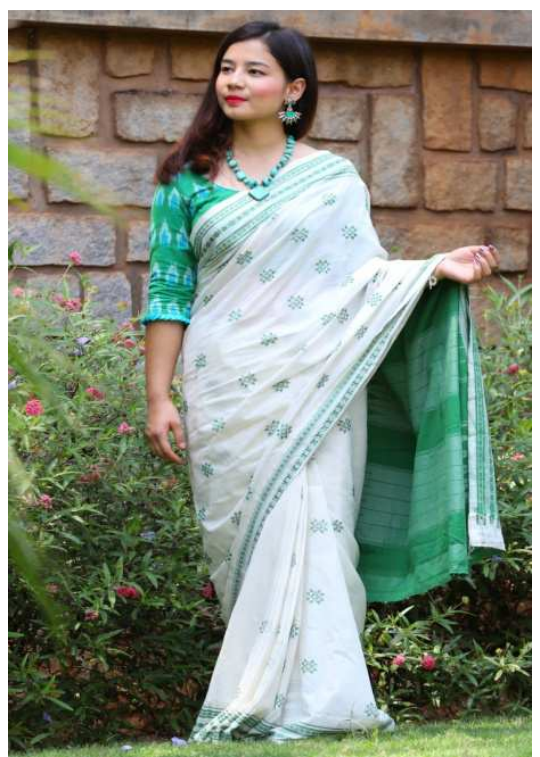

Figure 6: Sample 2- Developed Saree (Cotton*Bamboo)

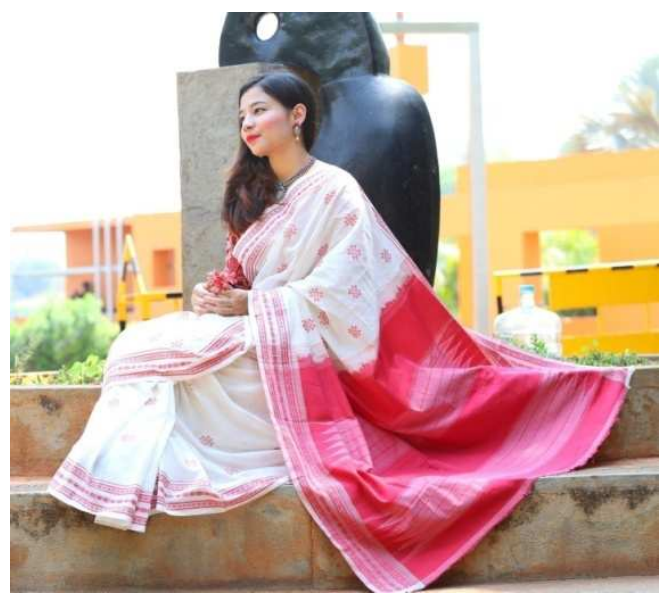

Figure 7: Traditional Ilkal Topeteni Seragu developed with Kondi Technique

\section{RESULTS AND DISCUSSIONS}

The data collected through the interview schedule and questionnaire for research study is tabulated and analyzed. From the tabulated data frequencies, percentages are calculated to know the opinion and acceptance level of designed sarees. The results are discussed below based on different factors.

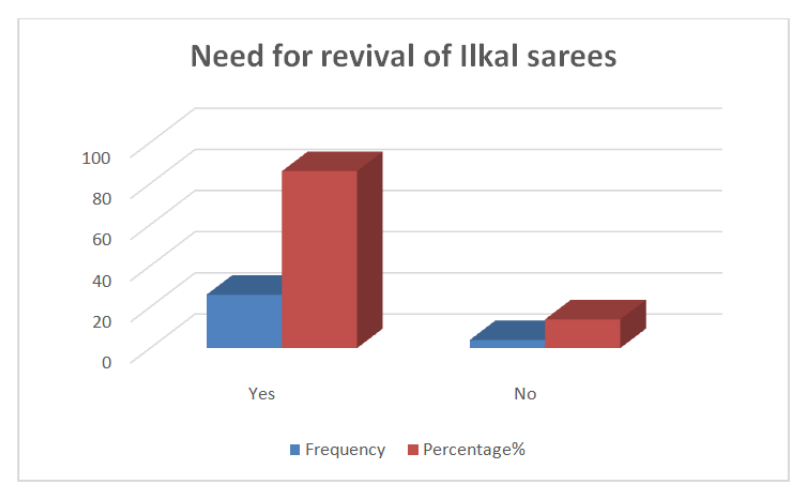

Figure 8 
The above graph explains that $86 \%$ of the weavers agreed there is a need for revival of Ilkalsarees and remaining $14 \%$ of weavers felt that the consumers may not accept the change especially the women from village background.

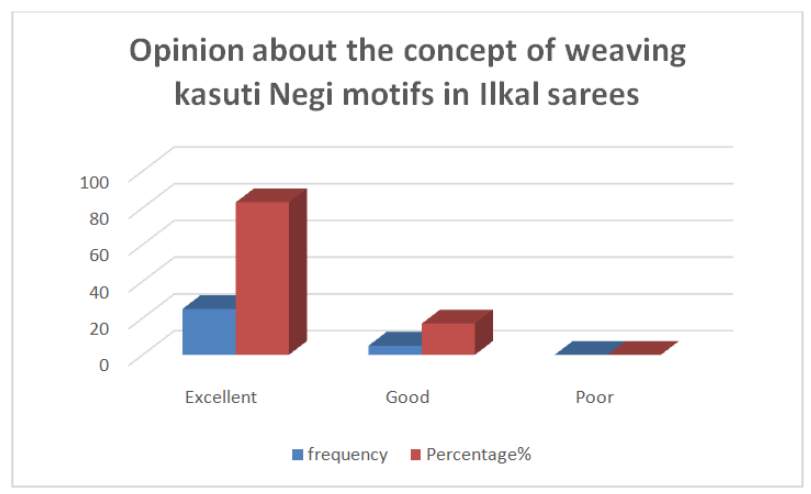

Figure 9

From the above graph it was found that, $86 \%$ appreciated the weaving of kasutiNegi motif in ilkal sarees is an excellent idea and remaining $14 \%$ of weavers felt it's a good concept that gives new variety in Ilkal sarees to the consumers who are seeking for change.



Figure 10

The above graph explains that $90 \%$ of weavers had given excellent rating for the sarees and remaining $10 \%$ rated it as a good one. The blend of regenerated cellulose yarns and new color combination has given a attractive look to the sarees.

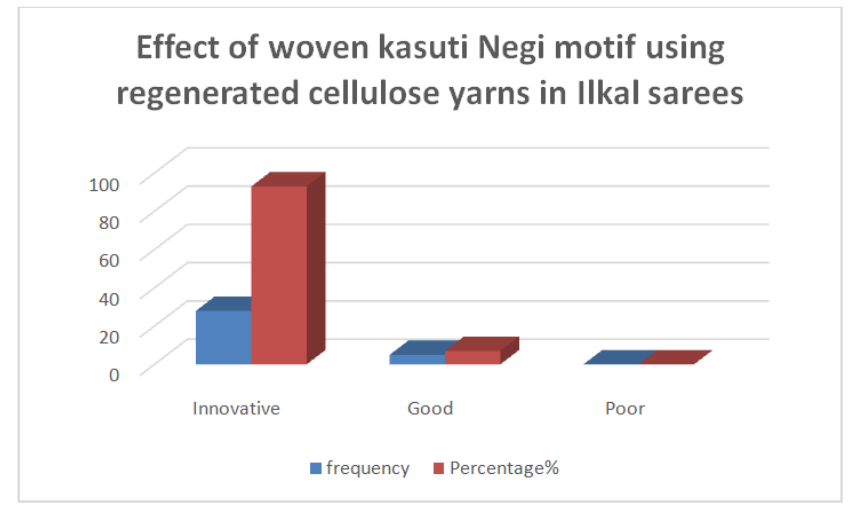

Figure 11 
The above graph explains that $93 \%$ of the weavers felt that the woven kasutiNegi motif and usage of modal, bamboo and banana fibers in Ilkalsaree is an innovative idea.7\% of the weavers felt it's a good concept that brings new variety in sarees. Weavers appreciated the efforts made to transfer hand embroidery to woven designs in Ilkalsarees. They said that the appearance is as beautiful as hand embroidery



Figure 12

The above graph gives the clear information about the acceptance of saree based on different factors.

- $90 \%$ of the weavers liked the color combination used for the saree, weavers appreciated it as an excellent concept, weavers expressed the usage of contrast color for the saree has given a new look which looks entirely different from the traditional saree. $10 \%$ of the weavers felt its good concept.

- $\quad 93 \%$ of the weavers expressed the texture of saree is excellent, which is soft and comfortable to wear during all the seasons like how the traditional sarees of Ilkalare worn during all seasons.7\% of the weavers felt the texture of the saree is good.

- $90 \%$ of the weavers felt the luster of the saree is enhanced by using modal fibers, $10 \%$ of the weavers felt the luster of the saree is good.

- $90 \%$ of the weavers have given a excellent rating for the overall appearance of sarees and remaining $10 \%$ of the weavers have rated it as good. Weavers stated that the new color and yarn combination in Ilkalsaree has given a special look for the saree.

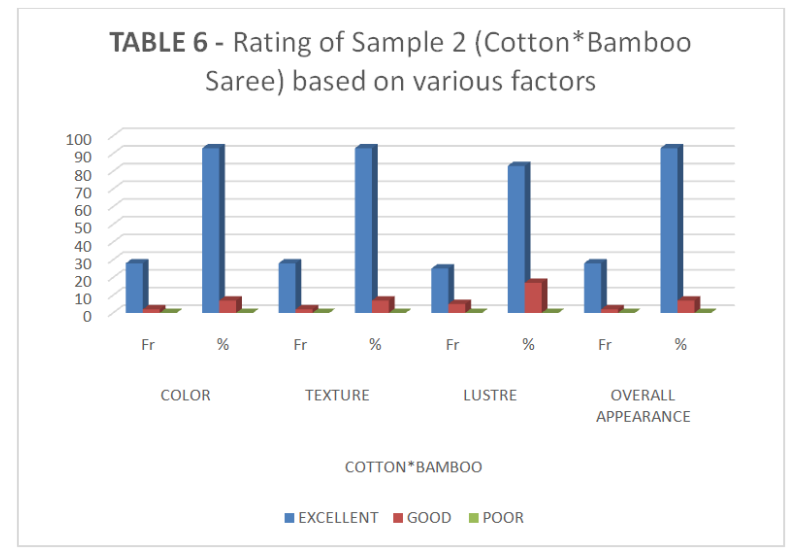

Figure 13 
From the above figure, it was found that

- $\quad 93 \%$ of the weavers liked the color combination, they expressed green color looks more bright and attractive on cream base.

- $\quad 93 \%$ of the weavers felt it has given an excellent texture which is smooth, soft and comfortable,7\% of weavers expressed saree has got a good texture with cotton and bamboo yarn combination.

- $\quad 83 \%$ of the weavers expressed the luster of saree is excellent and remaining $17 \%$ as good one.

- $\quad 93 \%$ of the weavers rated saree as an excellent one and remaining $17 \%$ as good one considering the overall appearance of the saree.

Thus from the above analysis, it was clear that weavers gave a positive response towards change in the yarn and color combination used without affecting the traditional technique and comfort properties. The weavers expressed that the usage of cream color as base with contrast color motif, boarder and pallu make the saree stand out uniquely.

\section{SUMMARY AND CONCLUSIONS}

"Old Wine in a New Bottle" can be aptly adopted by the Fashion industry. Textiles can be experimented with new styles and techniques while simultaneously retaining the ethnicity and uniqueness of it. With the aforesaid intent, the study was undertaken to create new variety in traditional textiles. Ilkalsarees that are commonly produced using cotton, silk and art silk, has been experimented with regenerated cellulose yarns such as modal, bamboo and banana yarns. These yarns are biodegredable, echo-friendly, stronger and antibacterial in nature. Two sarees are developed: one with cotton*modal and second one with cotton*bamboo and the motifs are woven using banana yarns. The kasutiNegi motifs are digitised and are transformed on to sarees during the weaving process itself unlike the earlier method that lets the embroidery work be done after the manufacturing of the saree which was more time-consuming in nature. The developed sarees are assessed by the traditional weavers. The weavers positively opined on the color combination, blend of regenerated cellulose yarns and traditional woven kasutiNegi motif. The employment of innovative techniques was well received. The efforts involved in revival of traditional Ilkalsarees is hopeful to elevate the saree to new heights.

\section{REFERENCES}

1. Pandit, S. 1976. Indian Embroidery- Its variegated charms. Jaymudra, Laxmi Estate, Bahuchargi Road, Baroda: 18-20.

2. $\quad$ Varughese G(1986)Towards revival of DharwadKasuti. Ind Tex J 97: 90-95.

3. Joshi, D. N.(1986) Grandeur of Gujarat embroidery. Indian Tex. J., 97 (1): 98 - 100.

4. Sahni S and Phadke S (1995) A study on card weaving. Ind Tex J 105: 14-22

5. Naik, S. D(1994)Traditional embroideries of India. A. P. H Publishing Corp., New Delhi, pp. 21 - 36.

6. Naik S (1996) Traditional embroideries of India: Kasuti of Karnataka. Pp 57-74, A. P. H Publishing Corporation 5, Ansari road, Darya Ganj, New Delhi

7. Singla S (1998) Adapting Kasuti embroidery to contemporary uses. M. Sc. thesis, Punjab Agricultural University, Ludhiana, India.

8. Rai, I. (2002) Problems and prospects in the 21st century. Books treasure, Jodhpur. Pp: 132-133. 
9. Vastrad, J. V.(2003)Weaving computerized negi motifs in traditional Lakkundi saris. Ph. D. Thesis, Univ. Agric. Sci., Dharwad (India).

10. Naik SD, Vastrad JV (2008) Protection and revival of traditional hand embroidery, Kasuti by automation. Indian Journal of Traditional Knowledge 7: 197-203.

11. Kakkanavar, Pramod R, Man-Made Textiles in India. Sep2008, Vol. 51 Issue 9, p317-319. 3p.

12. Singh, N., \& Rani, A. (2014). Needle punched non woven of Sesbania aculeate (Dhaincha) fibre. International Journal of Textile and Fashion Technology, 4(3), 7-12.

13. Kaur A (2010) Automation of hand embroidery motifs into self-woven designs. J AgriSci www.uasd.edu/publications.

14. Bennur, S. and Gavai, L. 2015, Regional traditional Indian embroidery "Kasuti" key success factors to reach the international markets. Journal of Textile Science \& Engineering. 5: 3.

15. Renu*, Nisha Arya, N. Chauhan and SumanSodhi,(2018) International Journal of Current Microbiology and Applied Sciences ISSN: 2319-7706 Volume 7 Number 04 